\title{
クレープのシボ設計に関する研究
}

（第 2 報）クレープ中の隣接する強撚糸間の位相差

$\begin{array}{ccccc}\text { 京都工芸繊維大学繊維学部 } & \text { 石 } & \text { 倉 } & \text { 弘 } & \text { 樹(会員) } \\ \text { " } & \text { 加 } & \text { 瀬 } & & \text { 晋 (会員) } \\ " & \text { 中 } & \text { 島 } & & \text { 勝 (会員) }\end{array}$

\section{Study on Crinkle Design of Crepe \\ Part 2 Analysis of the Phase Difference between \\ Contiguous Hard Twisted Yarn in Crepe}

\author{
Hiroki Ishikura, Susumu Kase and Masaru Nakajima \\ Kyoto Institute of Technology \\ Matugasaki, Sakyo-ku, Kyoto
}

\begin{abstract}
The former report show that the crinkle mechanism of crepe was a phenomenon of torsional buckling of yarns. If the elastic curve (the number and shape of helixes) of hard twisted yarns and the phase difference between contiguous hard twisted yarns were decided, the shape of crimps were determined.

And analysis for phase difference between hard twisted yarns in general crepe model was carried out, which uses hard twisted yarns for weft. The model was assumed that the phase difference was decided so that the deformation energy would be minimized by elongating warps in a reticulate fabric where there is no sliding between warps and wefts at their crossings. As the result, it was found that the phases became indentical when yarns twisted in the same direction were contiguous, and that when yarns twisted in the opposite directions were contiguous the phase difference depended upon the shapes of helixes. When the helixes were crushed to vertically to the fabric surface, the phase became identical, but when the helixes were crushed to horizontally to the surface or the helixes could be regarded as circles, the phase shifted by half.

Crepe were made by using silk and cotton yarns, in order to compare with the model fabric. From the comparison, it confirmed that the result can explain the phase difference between contiguous hard twisted yarns in crepe.
\end{abstract}

(Received December 9, 1991)

(Accepted for Publication March 3, 1992)

摘

要

目的 よこ糸に強撚糸を挿入したクレープの布中で隣接する強撚糸が作るらせんの位相差が決まる機構を明らかにする.

成果 たて糸のひずみエネルギーが最小になる位置に位相差が決まると考え, たて糸とよこ系の交差点を点接触と仮定した 布モデルにより, 単純化した条件下で位相差によるらせん発生時のたて系のひずみの 2 乗の総計を比較した. また実際のクレ一 プを試作し強撚糸が作るらせんの位相差を観察した。得られた結果の概要は次のとおりである.

(1)モデルによる解析では, 同方向の撚り糸が隣接すると位相は一致する.

(2)モデルによる解析では, 異方向の撚り糸が隣接するとらせんの断面形状により位相差は異なり, らせんが布面に対して垂直方 向につぶれた楕円らせんか真円に近い場合は位相は半周期ずれ, 布面に対して水平方向につぶれた棈円らせんでは位相が一致 する.

(3)試作結果は，(1)，(2)のモデル解析結果により良く説明できる. 


\section{1. 緒 言}

強撚系を製布することにより精練加工工程で布中 にシボと呼ばれる凹凸を発生さすクレープは，古く から多くの種類の糸を用いて広く衣服用布地として 使用されてきている.クレープはその外観と風合い に特徵を持ち, 用途に応じて撚系・布設計条件や加 工工程を変えることにより, 自然にさまざまなシボ を発生させることができる.

いままでこれらの設計や加工は経験的に行われて おり，シボ設計をその発生機構から力学的に解析し た研究は見られない.しかし今後の製品開発や高品 質化を考えるとシボ形状発現の基本的な機構を調べ ておくことは重要と思われる.

筆者らは前報1で, 引っ張りとねじりを受ける長 柱の力学モデルの解析とゴム系による実験および実 際のクレープとゴムクレープの観察から, クレープ のシボ発生が長柱の秝じり座屈現象であると考察 し，そのシボ発生機構を説明した。 クレープのシボ が系によるねじり座屈であるならば布中の各強撚系 も一種のらせん形状となることが予測される. また 経験的にもクレープ中の強撚糸が，らせん形をとる ことはよく知られている。 つまり一般に広く用いら れているよこ系に強然系を用いたクレープでは，隣 接するよこ糸間の位相差とよこ糸のらせん数および らせん形状が求まれば，シボ形状が決まると考えら れる，そこで本報ではよこ糸に強撚系を入れたクレ 一プを想定して, 隣接するよこ糸間のらせんの位相 差が決まる基本的な機構を検討した。

\section{2. 理 論}

シボ発生時には布中で各たて糸・よこ系が複雑な 変形を起こすが，その原動力となるのは強撚を受け ているよこ糸のねじりモーメントと考えられる，各 よこ糸が変形しようとして，たて糸や隣接するよこ 系に外力を与えたとき，系間に滑りがないとすると 変形に対して特に大きな抵抗となるのは, 直線状の 糸材料の場合系軸方向の引っ張りに対する抵抗力で あると考える。よこ系同士で及ぼし合う力は糸軸に 対してほぼ垂直にかかるため，上こ系の糸軸方向に 引っ張る力は無視できる，つまりよこ系の変形によ り生じるたて糸の引っ張りに関する变形エネルギー が最す小さいところで隣接するよこ糸の位相差が決 まると考える.

以上の仮説のもとで隣接する強撚糸のらせんの位
相差を次のような仮定を設定して予測した。

a ）隣接するよこ系のらせんの巻き方向は同方向之 異方向を考えるが，大きさ・ピッチ等のらせん 形状は同一とする.

b ）たて糸とよこ糸の交差点の接合条件は点接触と する.

c）たて糸はよこ系の中心線間をつないでおり，よ こ糸の中心線間距離は変化しない.

d）系の太さは無視する.

e ）たて糸の荷重一伸びの関係は線形とする.

a ）を仮定したのは，現在製造されているクレー プの多くは，撚りが 1 方向だけの強撚系を用いた製 品, $\mathrm{S} \cdot \mathrm{Z}$ 方向の強撚糸を何本かずつ交互に用いた 製品であるが，それらの布中の各強撚系の撚数は一 定に設計されているためである.

図 1 はらせんを発生した隣接する撚系間の関係を 表しており，強撚のよこ系間をたて糸がつないでい ると考える. 図 2 は解析のよこ系モデルであるが, らせんを $\mathrm{X}$ 一Y 面から見たときの楕円の形 (以下ら せんの断面形状と呼ぶ）と Z 軸方向の波の位相差 （以下位相差と呼ぶ）を変化させて, 同方向, 異方向 それぞれの撚糸が隣接する場合の，1らせん間のた て糸の総変形量を計算する.このモデルでの中で,

e）で仮定したようにたて糸の荷重一伸びは線形で あるとすると，たて系のひずみを 2 乗した值の総計
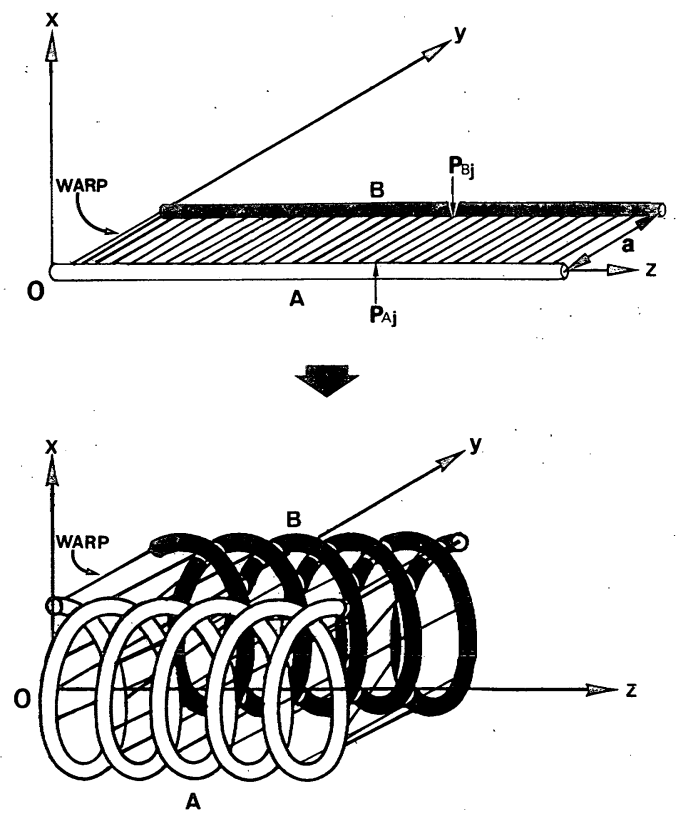

Fig. 1 Model of contiguous helical yarns. 

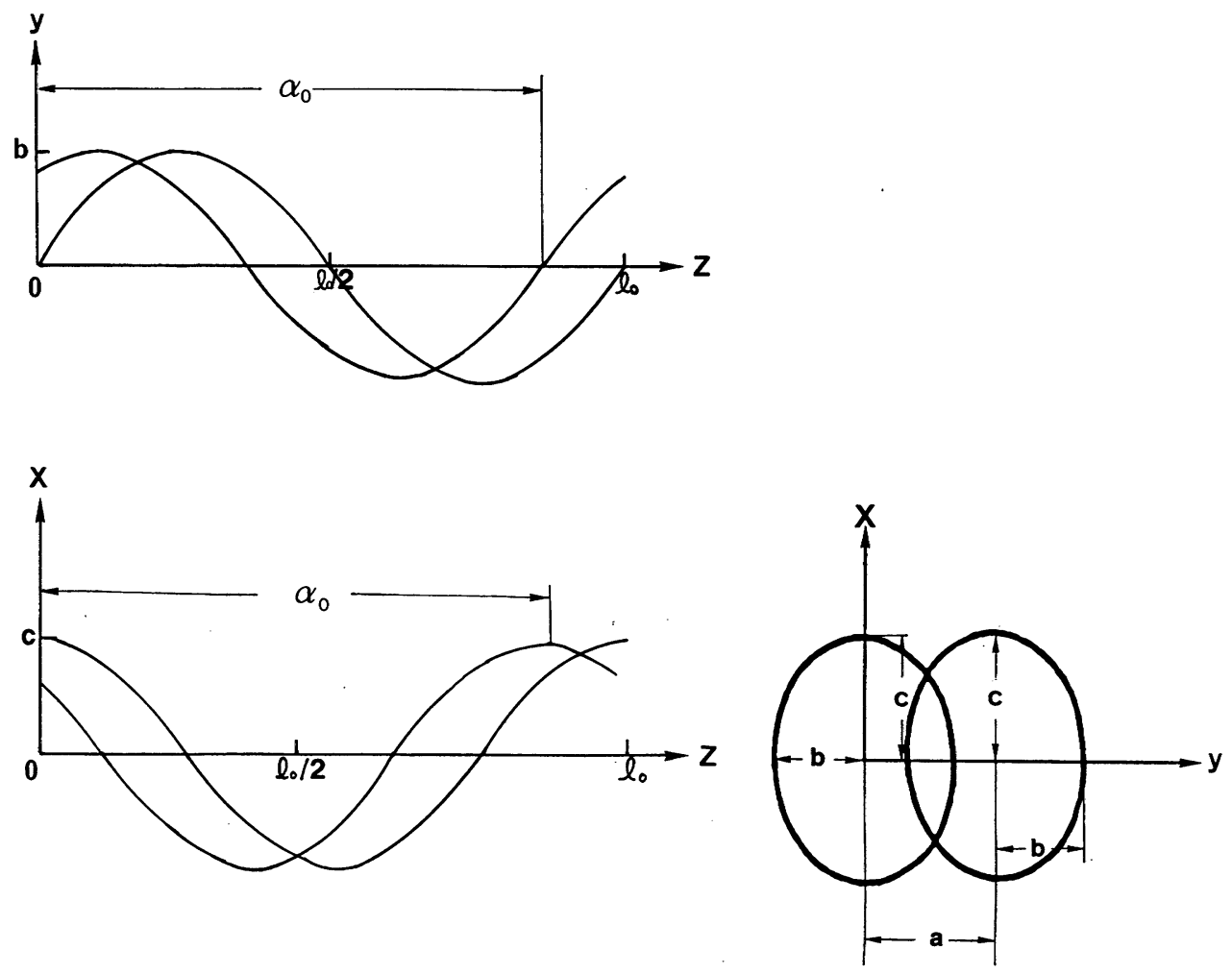

Fig. 2 Contiguous helical yarns model with phase difference.

が最む小さくなる位置で引っ張りのひずみエネルギ 一が最小となり，隣接する強撚系間の位相差が決ま る.

\section{1 隣接する強撚糸の撚り方向が同じ場合の 計算}

空間座標 $0-x y z$ の $z$ 軸に糸軸を一致させてよこ たわる直線状の強撚系 $A$ と $y$ 軸方向に $a$ の距離を おいて $A$ と平行によこたわる強撚系 $B$ を考え，た て糸が $A, B$ の間を $z$ 軸に対して一定間隔でつない でいるとする. その後 $A, B$ が前述の仮定 $a) \sim d$ ) 下でらせんをとるとする．このとき $A, B$ が位相差 $\alpha_{0}$ を有すると, $A, B$ の位置関係は図 2 で表せる. らせん $A, B$ はそれぞれ(1)，(2)式となる.

$$
\left.\begin{array}{l}
x=c \cos 2 \pi \frac{z}{\ell_{0}} \\
y=b \sin 2 \pi \frac{z}{\ell_{0}}
\end{array}\right\}
$$

$$
\left.\begin{array}{l}
x^{\prime}=c \cos 2 \pi \frac{z+\alpha_{0}}{\ell_{0}} \\
y^{\prime}=b \sin 2 \pi \frac{z+\alpha_{0}}{\ell_{0}}+a
\end{array}\right\}
$$

上式により任意の $i$ 番目のたて糸がらせん発生前 に $A, B$ と交差していた点をそれぞれ $P_{A i}, P_{B i}$ とす る之, $A, B$ が同一方向のらせんの場合, らせん発生 後の $P_{A i}, P_{B i}$ 間を結ぶ直線の $x$ 軸方向の距離 $x_{i}$ は(3) 式となり,

$$
\left|c \cos 2 \pi \frac{i d}{\ell_{0}}-c \cos 2 \pi \frac{i d+\alpha_{0}}{\ell_{0}}\right|=x_{i}
$$

$d$ : 隣接するたて糸の中心線間の距離

$l_{0}: 1$ らせんの $z$ 軸方向の長さ $y$ 方向の距離は(4)式となる.

$$
\left|b \sin 2 \pi \frac{i d}{\ell_{0}}-b \sin 2 \pi \frac{i d+\alpha_{0}}{\ell_{0}}-a\right|=y_{i}
$$

変形前の $P_{A i}, P_{B i}$ 間の距離は $a$ なので, たて糸 $i$ の ひずみ $\varepsilon_{i}$ は(5)式となる。

$$
\frac{\sqrt{x_{i}^{2}+y_{i}^{2}}-a}{a}=\varepsilon_{i} \quad\left(\varepsilon_{i}>0\right)
$$




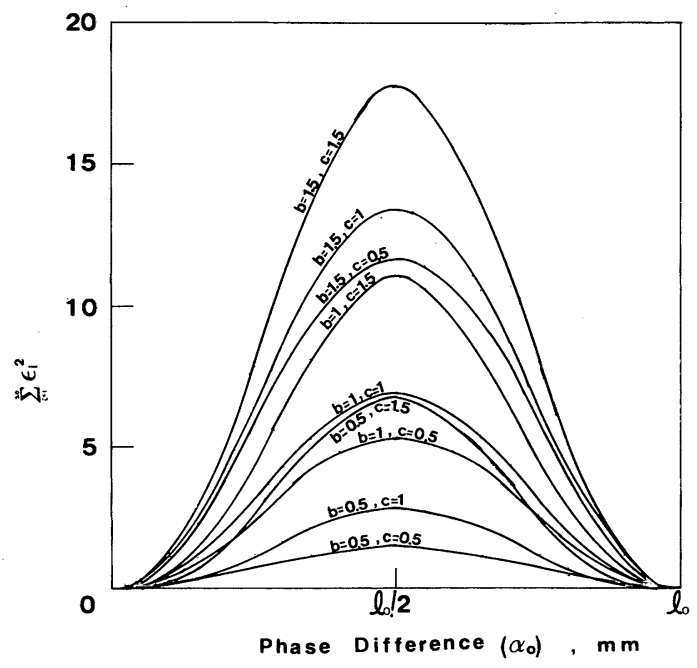

Fig. $3 \sum \varepsilon_{i}^{2}$ of warp by change of phase difference for one period.

(Same directional helixes, warp $\mathrm{n}=20$ )

強撚系が 1 らせん間に $n$ 本のたて糸と交差してい るとすると，1 らせん間のたて糸のひずみの 2 乗の 総計は $\sum_{i=1}^{n} \varepsilon_{i}{ }^{2}$ となり, $\sum_{i=1}^{n} \varepsilon_{i}{ }^{2}$ が最む小さくなる位置にら せん間の位相差が決まると考える.

図 3 は 1 らせん間のたて糸本数を 20 本, $a=2$. $\mathrm{mm}$ を仮定して, 各らせん形状下での位相差と 1 ら せん間のたて系の総変形量を計算した結果を示して いる. この図から隣接する強撚系間の位相が一致す るときは, 形状に関係なくたて糸がひずまずにらせ んをとることができ, 位相差が半周期に近づくに従 い，たて糸がひずまないとあらかじめ与えられたら せんの断面形状をとれないことが分かる.つまり本 モデルによる解析では, 隣接する同方向撚りの強撚 糸間の位相はらせんの断面形状に関係なく一致する ことになる.

\section{2 隣接する強撚糸の撚り方向が逆の場合の 計算}

撚り方向が同じ場合と同様に, らせん発生前に任 意の $j$ 番目のたて糸が強撚系 $A, B$ 交差していた 点を $P_{A j}, P_{B j}$ とする. らせん発生後 $A, B$ は(6), (7) 式となり,

$$
\left.\begin{array}{l}
\left.\begin{array}{l}
x=c \cos 2 \pi \frac{z}{\ell_{0}} \\
y=b \sin 2 \pi \frac{z}{\ell_{0}}
\end{array}\right\} \\
x^{\prime}=c \cos 2 \pi \frac{z}{\ell_{0}} \\
y^{\prime}=-b \sin 2 \pi \frac{z}{\ell_{0}}+a
\end{array}\right\}
$$

$P_{A j}, P_{B j}$ 間を結ぶ直線の $x$ 軸方向の距離は(8)式とな り,

$\left|c \cos 2 \pi \frac{j d}{\ell_{0}}-c \cos 2 \pi \frac{i d+\alpha_{0}}{\ell_{0}}\right|=x_{j}$

$y$ 軸方向の距離は(9)式となり,

$$
\left|b \sin 2 \pi \frac{j d}{\ell_{0}}+b \sin 2 \pi \frac{j d+\alpha_{0}}{\ell_{0}}-a\right|=y_{j}
$$

$j$ 番目のたて糸のひずみ $\varepsilon_{j}$ は(10)式となる.

$$
\frac{\sqrt{x_{j}^{2}+y_{j}^{2}}-a}{a}=\varepsilon_{j} \quad\left(\varepsilon_{j}>0\right)
$$

強撚系が 1 らせん間に $n$ 本をたて系と交差してい るとすると強撚系 1 らせん間のたて糸のひずみの 2 乗の総計は $\sum_{i=1}^{n} \varepsilon_{j}^{2}$ となる.

図 4 は図 3 と同条件で 1 らせん間の $\sum_{i=1}^{n} \varepsilon_{j}^{2}$ を計算 した結果である.この図から, らせんの断面形状が

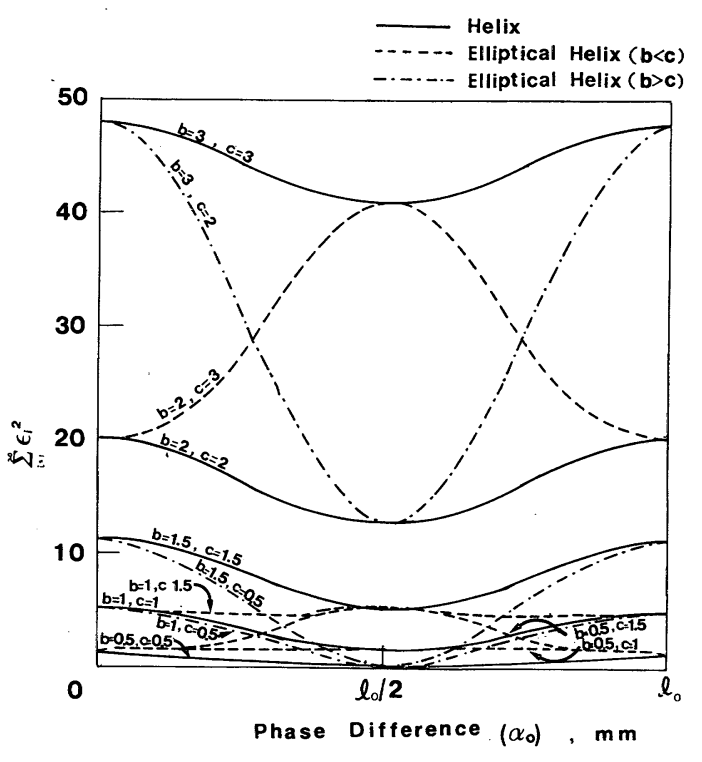

Fig. $4 \sum \varepsilon_{j}^{2}$ of warp by change of phase difference for one period. (Reverse directional helixes, warp $n=20$ ) 
$x$ 軸方向に長い楕円らせんと真円に近いらせんの場 合, 位相が半周期ずれた位置でたて糸のひずみエネ ルギーが最小になり， $y$ 軸方向に長い楕円らせんで は位相が一致するときに，たて糸のひずみエネルギ 一は最小になることが分かる。つまり本モデルによ る解析からは, 強撚系のらせん断面が布面に対して 垂直につぶれた楕円らせんか真円に近いらせんをと るときには位相が半周期ずれること，布面に対して 水平につぶれた楕円らせんをとるときには位相が一 致することが予測できる.

また本モデルによると，同方向の撚りの糸が隣接 した場合は位相が一致すればたて糸が全くひずまな
くてあらせん形状をとることができるが，逆方向の 撚りの糸が隣接した場合はらせんの断面形状を問わ ずたて糸のひずみが必要であることが分かる.

\section{3. 実 験}

\section{1 実験試料}

絹糸と綿糸を使用して，それぞれ S 撚りと Z 撚り を同本数ずっ交互によこ系に挿入して製織を行っ た。作成した試料の製造工程を図 5 ，図 6 に設計条 件を表 $1 ， 2$ に示す.

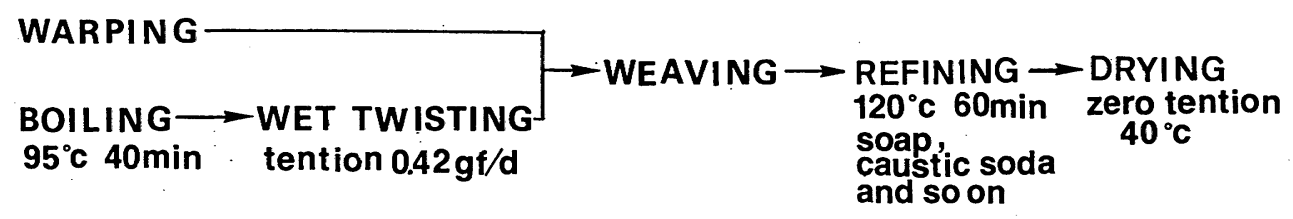

Fig. 5 Trial manufacturing process of silk crepe.

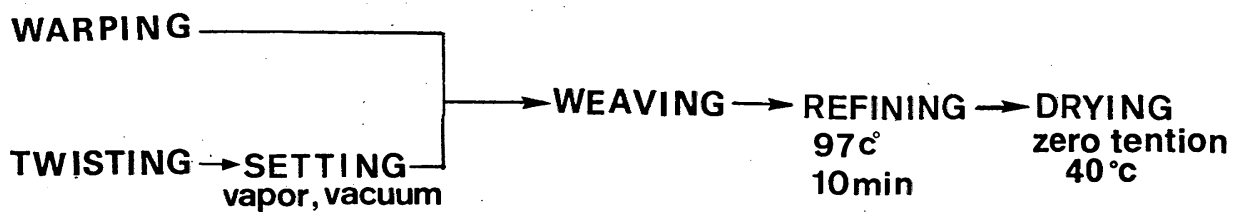

Fig. 6 Trial manufacturing process of cotton crepe.

Table 1 Design conditions of silk crepe samples.

\begin{tabular}{|c|c|c|c|c|c|c|}
\hline \multirow{2}{*}{$\begin{array}{l}\text { Symbol of } \\
\text { Silk crepe } \\
\text { al }\end{array}$} & \multicolumn{2}{|c|}{$\begin{array}{l}\text { Density } \\
\text { Ends Picks } \\
(1 / \mathrm{cIII})\end{array}$} & $\begin{array}{l}\text { Yain } \\
\text { Warp } \\
\text { (te. }\end{array}$ & $\begin{array}{l}\text { ounts } \\
\text { Weft } \\
?\end{array}$ & \multirow{2}{*}{$\begin{array}{l}\text { Twist Number } \\
\text { of Weft } \\
(t / 11)\end{array}$} & \multirow{2}{*}{$\frac{\text { Twist Direction }}{s-2}$} \\
\hline & 53 & 16 & $3.0 / 14$ & $4.7 \times 9$ & & \\
\hline$a 2$ & 53 & 16 & $3.0 / / 4$ & $4.7 \times 9$ & 2600 & $s-s-z-z$ \\
\hline a3 & 53 & 16 & $3.0 / / 4$ & $4.7 * 9$ & 2600 & $s-s-s-z-z-z$ \\
\hline al & 53 & 16 & $3.0 / / 4$ & $4.7 \times 9$ & 26,00 & $s-s-s-s-z-z-z-z$ \\
\hline $\mathrm{a} 5$ & 53 & 16 & $3.01 / 4$ & $4.7 * 9$ & 2600 & $2-2-2-2-2-z-z-z-5-z$ \\
\hline$a 6$ & 53 & 16 & $3.0 / / 4$ & $4.7 \times 3$ & 2600 & 2 \\
\hline
\end{tabular}


Table 2 Design conditions of cotton crepe samples.

\begin{tabular}{|c|c|c|c|c|c|c|}
\hline \multirow{2}{*}{$\begin{array}{l}\text { Symbol of } \\
\text { Cotton Crepe } \\
b 1\end{array}$} & $\begin{array}{l}\text { Density } \\
\text { Ends } \\
(1 / \mathrm{cIII})\end{array}$ & Picks & $\begin{array}{c}\text { Varr } \\
\text { Warp } \\
(\end{array}$ & $\begin{array}{l}\text { Counts } \\
\text { Weft } \\
x)\end{array}$ & \multirow{2}{*}{$\begin{array}{c}\begin{array}{c}\text { Twist Number } \\
\text { of Weft } \\
(t / \mathrm{II})\end{array} \\
1800\end{array}$} & \multirow{2}{*}{ Twist Direction } \\
\hline & 43 & 13 & 11.8 & $19.7 * 2$ & & \\
\hline b2 & 43 & 13 & 11.8 & $19.7 * 2$ & 1800 & $s-s-2-2$ \\
\hline b3 & 43 & 13 & 11.8 & $19.7 * 2$ & 1800 & $s-s-s-z-z-z$ \\
\hline b4 & 43 & 13 & 11.8 & $19.7 * 2$ & 1800 & $s-2-s-s-z-z-z-z$ \\
\hline b5 & 43 & 13 & 11.8 & $19.7 * 2$ & 1800 & $2-2-2-2-2-z-z-z-z-z$ \\
\hline b6 & 43 & 13 & 11.8 & $19.7 * 2$ & 1800 & $\begin{array}{r}-z-5-z-z-z-z-z-z-z-z \\
2-2-2-2-2-2-2-2-2-2\end{array}$ \\
\hline b7 & 43 & 13 & 11.8 & $19.7 * 2$ & 1800 & $s$ \\
\hline
\end{tabular}

*: Twisted Yarn

\section{2 測定方法}

3.2.a 隣接するよこ系間の位相差：各よこ糸の 撚り方向を調べながら, 位相差を観察した.

3.2.b らせんの断面形状：よこ系の布面内の, 糸幅を含めたうねりの振幅を立体顕微鏡で測定する とともに, KES-F (カトーテック製) 圧縮試験機に より圧縮力 $5 \mathrm{gf} / \mathrm{cm}^{2}$ で厚さを測定した.

\section{4. 実験結果}

図 7 に絹糸を用いた試料, 図 8 に綿系を用いた試 料の写真を示す.これらより両グループとも同様の 傾向を持つことが分かる.

$\mathrm{S}$ 撚と $Z$ 撚が 1 本交互に挿入されている a $1, \mathrm{~b}$ 1 では隣接するよこ糸間のらせんの位相差はランダ ムであり，綿糸を用いている b 1 ではところどころ スナールが発生している. S 撚りと $Z$ 撚りを 2 本ず つ交互に挿入している a 2, b 2 では, 位相の一致し たよこ系と半周期ずれた逆方向のらせんのよこ糸が それぞれ 2 本ずつ交互に並んでいることが観察でき る.これらのよこ系の撚り方向を調べると， 2 本並 んで位相が一致している系同士は同方向の撚りで, 半位相ずれるところで撚り方向が変わっていた。っ
まり同方向の撚りが隣接するよこ糸間では位相が一 致し, 逆方向の撚と隣接するところでは位相が半周 期ずれている.このことは絹系の同方向の撚りを 3 本ずつ交互から 5 本ずつ交互に挿入した試料 a 3 , a 4, a 5, 綿系の同方向の撚系を 3 本ずつ交互から 10本ずつ交互まで挿入した試料 b 3, b 4, b 5, b 6 でも同じ結果であり，撚り方向が変わるところでの 半周期のずれは, 同方向の撚りのよこ糸が多く並ぶ ほど明確になる傾向を示す. a 6 と b 7 はそれぞれ $Z$ 撚だけと $\mathrm{S}$ 撚だけをよこ系として挿入した試料で あるが両試料とも位相が一致していることが分か る. また同方向の撚りの糸を連続して多く挿入する ほどらせんが大きくなり，らせん数は少なくなって いる.

図 9 は各試料の布厚と布面内で振幅するよこ系の 曲がり量との関係を示している. 絹クレープ, 綿ク レープとも $\mathrm{S}$ 撚りと $Z$ 撚りが 1 本交互の試料以外 全般に布厚に対して振幅が大きな值をとっているこ とが分かる. $\mathrm{S}$ 撚りと $Z$ 撚りが挿入されている試料 では同方向の撚りの糸を連続して多く並べるほど布 厚, 振幅とも大きくなっており, 特に綿クレープの 振幅の増大が顕著である. 

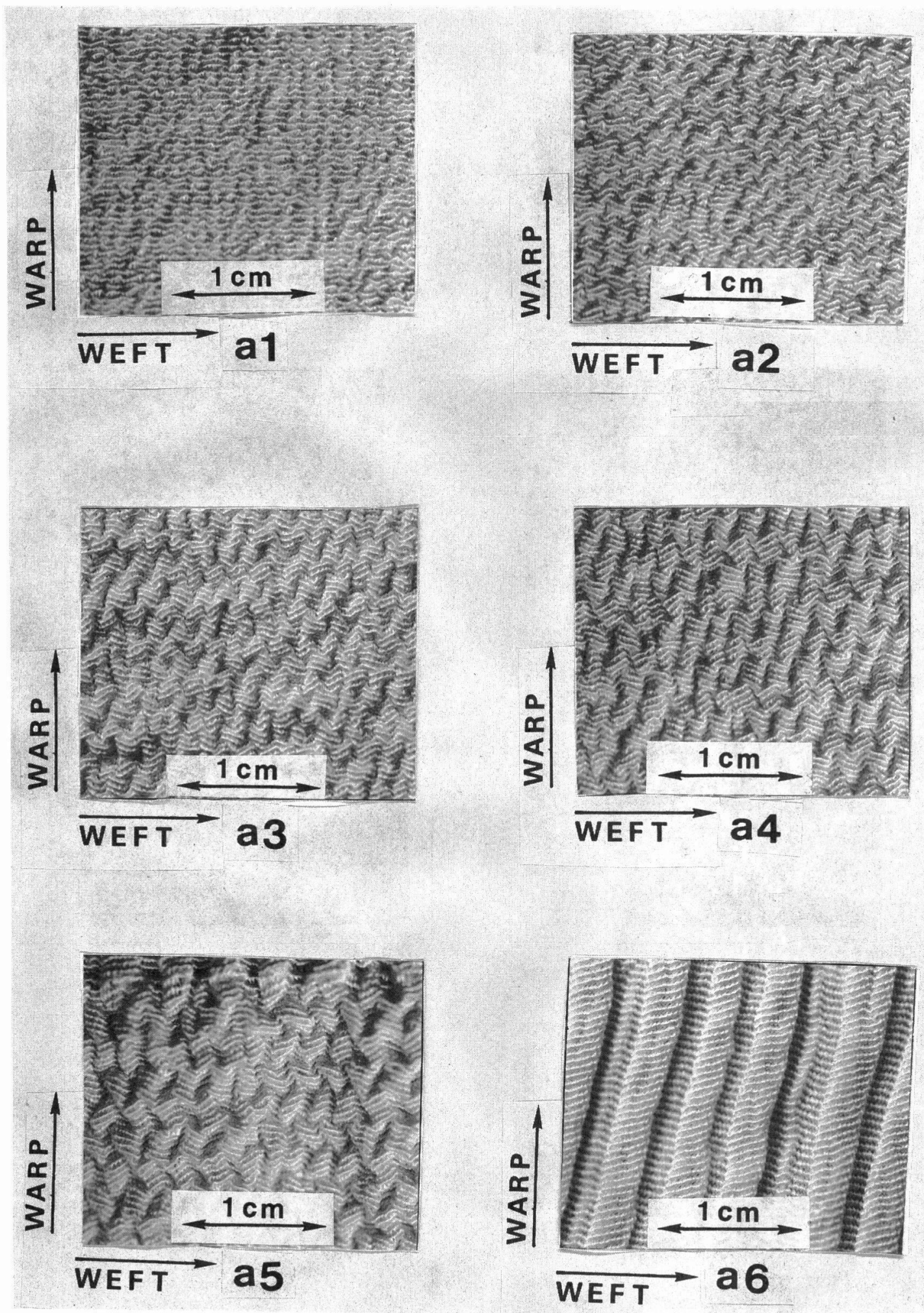

Fig. 7 Structure of silk crepe by arrangement of hard twisted yarns. 

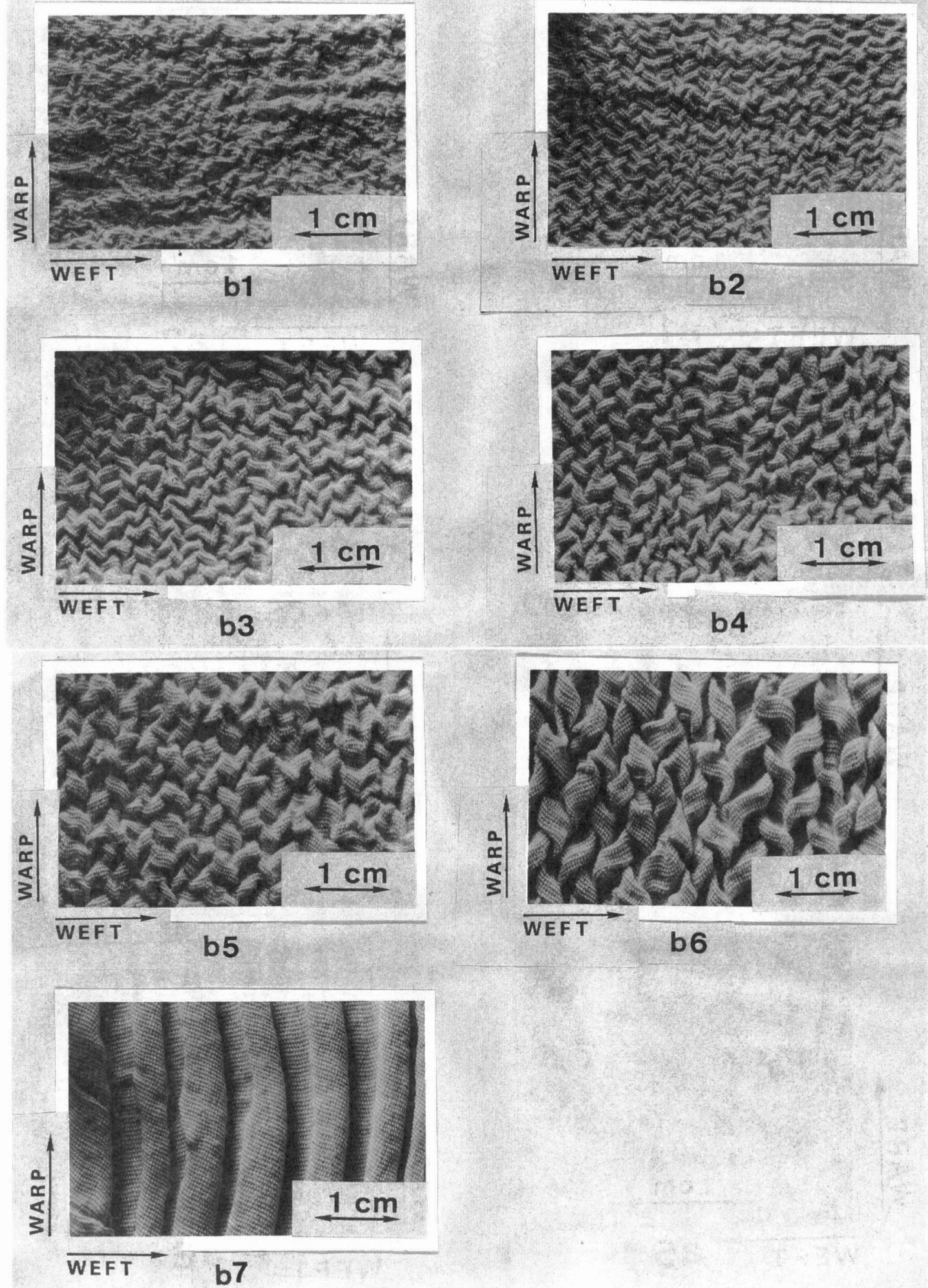

Fig. 8 Structure of cotton crepe by arrangement of hard twisted yarns. 


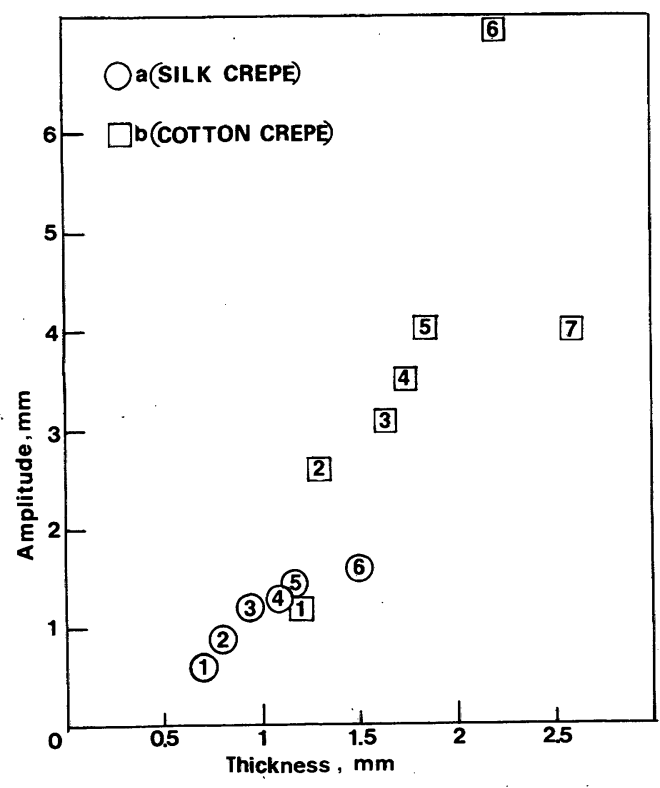

Fig. 9 Relation between amplitude and fabric thickness.

\section{5. 考 察}

試織したクレープの観察結果から, 理論で説明し た仮説の適応性は高いと考えられる. 同方向の撚り が隣接して並んでいる場合それらの位相は例外無く 一致しており，モデルによる計算結果と合う。逆方 向の撚りが隣接した場合 $\mathrm{S}$ 撚りと $Z$ 撚りが 1 本ず つ交互に入る以外では位相は半周期ずれており，布 厚と布面に水平方向のらせんの振幅の関係を見る と, 布厚に対して振幅が大きな值を示しているこ と. 布厚と振幅がらせん断面の楕円の径の関係を表 しているとするとこれらすモデルによる計算とよく 一致する.

$\mathrm{S}$ 撚りとZ 撚りが 1 本ずつ交互に亚んでいる試料 は絹クレープ, 綿クレープともに位相差は不規則で ある. $\mathrm{S}$ 撚りと Z 撚りが 1 本交互に並んだ綿クレー プでスナールが発生していることから以下の様に考 える. 図 4 に示したように, 逆方向の撚りの強撚系 が隣接した場合, らせんの断面形状や位相差にかか わらずたて糸は必ず伸びることを要求される，逆方 向の撚りが 1 本ずつ交互に隣接するとよこ系 1 本ご とにたて糸が伸びなければならなくなるが，実際に は抵抗力が大きいため伸びることができない，そこ でたて糸とよこ系の間に大きな滑りが起こり，仮定 b）が成り立たなくなり，たて糸がよこ系をつなぐ 役目を充分果たせなくなる．またこのようにたて糸 による拘束が大きいため，各よこ糸が規則的ならせ んをとりにくくなっていることも影響していると思 われる。

また.S 撚りとZ 撚りの両方が挿入された試料で は同方向の撚りが連続して並ぶ本数が少なくなるほ ど布厚が小さくなるのは，先に図 4 より考えたよう に撚り方向が頻繁に逆になるとたて糸が引っ張られ たて系の張力が大きくなり，よこ系が布面に垂直な 上下方向から押されるためと考える.

\section{6. 結 言}

よこ糸に強撚系を挿入した一般的なクレープにつ いて，布中の隣接する強撚系のらせん間の位相差を 検討した．たて糸とよこ系の交差点をピンジョイン トとし，たて糸の糸軸方向の変形エネルギーが最も 小さくなる位置にらせんの位相差が決まると考えて さまざまな形のらせんについて計算を行い実験結果 と比較したところ，本報の仮説とモデルにより実際 のクレープの強撚系間の位相差がほぼ説明できるこ とが分かった．得られた主な結果は以下のとおりで ある.

1）モデルによる計算では，隣接する強撚系のらせ ん方向が同じ場合, らせん形に無関係に位相は一致 する.

2) モデルによる計算では, 隣接する強撚系のらせ ん方向が逆の場合，らせんが布面に垂直方向につぶ れた棈円らせんではらせんの位相は半周期ずれ，布 面に水平方向につぶれた棈円らせんでは位相は一致 し, らせんの断面形状が真円に近い場合位相は不規 則になる.

3）各種の絹クレープと綿クレープを試作して隣接 する強撚系のらせんの位相差を調べたところ, 同方 向の撚りの系が隣接している位置では位相は一致し た。

4 ) 各種の絹クレープと綿クレープを試作して隣接 する強撚系のらせんの位相差を調べたところ, 逆方 向の撚りの糸が隣接している位置では, $\mathrm{S}$ 撚りと Z 撚りが複数本ずつ交互の挿入されている試料で半周 期の位相差があり，1本ずつ交互に挿入されている 試料では位相差は不規則であった。

5）4）の結果は布厚を強撚系のらせんの布面に垂 直方向の振幅之考えると計算結果之一致する.

6) $S$ 撚りと Z 撚りを何本かずつ交互に用いてクレ 
ープを試作した結果同方向の撚りの糸を連続して多 く並べるほどらせんが大きくなりらせん数は小さく なった

謝辞 著者のひとり石倉弘樹は社会人入学の学生と して本研究を行っている. 本研究の機会を与えてい ただいた滋賀県繊維工業指導所前川春次所長, 中川
哲高島支所長に感謝の意を表します。また試料の試 作にご協力睗りました滋賀県緎維工業指導所の関係 の方々に深謝致します。

\section{文献}

1）石倉弘樹, 加瀬晋, 中島勝; 絨機誌, 44, T 260 (1991)

\section{正 誤 表}

本誌 Vol. 44, No. 12 (平成 3 年12月号) T 260 「クレープのシボ設計に関する研究（第 1 報）」に誤まりがあり ましたので訂正します.

- T 260 の Abstract 5 行目「Therfore $\rightarrow$ 「Therefore $\lrcorner$

○ T 262 の(3)式 $\left\ulcorner\cdots \cdots-i M_{2} \frac{d^{3} \vec{r}_{x y}}{d z^{3}} \cdots \cdots ..\right\lrcorner \rightarrow\left\ulcorner\cdots \cdots-i M_{z} \frac{d^{3} r_{x y}}{d z^{3}} \cdots \cdots .\right.$.

○T 262 の(7)式 $\left\ulcorner D-i \lambda D-\mu=0\right.$ より」 $\rightarrow\left\ulcorner D^{2}-i \lambda D-\mu=0\right.$ より」

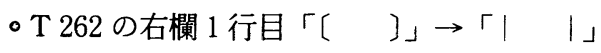

- T 262 の右欄 7 行目 $\left\ulcorner e^{\beta}=e^{\frac{1}{2} i\left(\lambda+\sqrt{\lambda^{2}-4 \mu}\right)}\right\lrcorner \rightarrow\left\ulcorner e^{\beta}=e^{\frac{1}{2} i\left(\lambda-\sqrt{\lambda^{2}-4 \mu}\right)}\right\lrcorner$

○ T 263 の(23)式 $\left\ulcorner-\left(\cos \alpha^{\prime}+i \sin \alpha^{\prime}\right) \cdots \cdots\right\lrcorner \rightarrow\left\ulcorner\alpha^{\prime} \beta^{\prime}\left\{\left(\cos \alpha^{\prime}+i \sin \alpha^{\prime}\right) \cdots \cdots\right.\right.$.

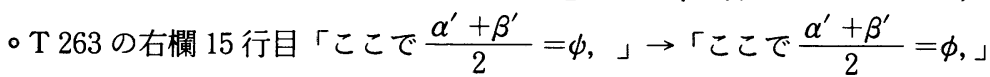

-T 263 の右欄 $16 〜 18$ 行目および $24 \sim 27$ 行目の「 $\phi_{\lrcorner}$はすべて「 $\left.\phi\right\lrcorner$

○T 264 の左欄 3 行目 $\ulcorner\phi\lrcorner は\ulcorner\phi 」$

- $\mathrm{T} 264$ の左闌 8 行目 $\left\ulcorner e^{\alpha+\beta}=e^{i \lambda}=\operatorname{cso} \lambda+i \sin \lambda\right\lrcorner は\left\ulcorner e^{\alpha+\beta}=e^{i \lambda}=\cos \lambda+i \sin \lambda\right\lrcorner$

○ T 265 の右欄 21 行目 $\left\ulcorner\ldots . . . .990^{\circ} \mathrm{C}\right.$ 異なる……」 $\rightarrow\left\ulcorner\cdots . . . . .990^{\circ}\right.$ 異なる……」

○T 267 の参考文献 6 ）「……繊維機械学会論文集」 $\rightarrow\ulcorner. . . .$. 機械学会論文集」 